

\title{
Lower Cambrian trace fossils from the Buen Formation of central North Greenland: preliminary observations
}

\author{
Ian D. Bryant and Ron K. Pickerill
}

\begin{abstract}
The trace fossils Cruziana cf. C. stromnessi (Trewin, 1976), Curvolithus Fritsch, 1908, Hormosiroidea Schaffer, 1928, Monomorphichnus cf. M. bilinearis Crimes, 1970, Monomorphichnus lineatus Crimes et al., 1977, cf. Palaeobullia Götzinger \& Becker, 1932, Palaeophycus tubularis Hall, 1847, Phycodes pedum Seilacher, 1955, Psammichnites Torell, 1870, Rusophycus Hall, 1852, Skolithos Haldeman, 1840 and cf. Zoophycos Massalongo, 1855 are recorded and briefly described from the Lower Cambrian Buen Formation, central North Greenland. Interbedded sandstones, siltstones and shales of the Buen Formation were deposited in a tide and stormdominated shallow marine shelf environment. Ichnofaunal diversity is low in monolithologic cross-bedded sandstones, which characterise the basal portion of the sequence, and considerably higher in heterolithologic sandstones, siltstones and shales, which occur higher in the sequence.
\end{abstract}

I. D. B., Kon./Shell Exploratie Produktie Laboratorium, Postbus 60, 2280 AB Rijswijk $(\mathrm{ZH})$, Nederland. Present address: Shell, BP \& Todd Oil Services Ltd., Private Bag, New Plymouth, New Zealand.

R. K. P., Department of Geology, University of New Brunswick, Fredericton, N.B., Canada, E3B $5 A 3$.

Seilacher (1956) was the first to recognise that trace fossils could provide an important tool in correlating sparsely fossiliferous Precambrian to Lower Cambrian sequences and potentially play an important role in the establishment of the Precambrian-Cambrian boundary on a global basis. Since then, more detailed analyses of Precambrian and Cambrian ichnofaunas have been undertaken from almost every continent apart from Antarctica (see Crimes, 1987; Narbonne et al., 1987 for reviews). However, as noted by those authors, Precambrian and Lower Cambrian trace fossils are poorly known from Greenland. Cowie \& Spencer (1970) described a selection of Lower Cambrian trace fossils from the Bastion and Ella Island Formations of North-East Greenland based on a few slabs collected during a reconnaissance survey. Pickerill \& Peel (1990) described a significantly larger amount of material from the Bastion Formation and provided a taxonomic re-assessment of the previous collections. Bergström \& Peel (1988) have also described several additional arthropod-produced trace fossils from the Lower Cambrian Dallas Bugt, Buen and Humboldt Formations of northern Greenland. To date, however, these are the only detailed reports on Lower Cambrian trace fossils from Greenland.
This paper briefly describes a selection of trace fossils collected by I. D. B., as part of field work carried out by the Geological Survey of Greenland in 1984, from the Buen Formation (middle to late Early Cambrian) exposed in the land area south of Nares Land, central North Greenland (fig. 1). Rusophycus marginatus Bergström \& Peel, 1988, reported by Bergström \& Peel (1988) from Peary Land, represents the only ichnospecies described previously from the Buen Formation. However, Hurst \& Peel (1979) illustrated Skolithos Haldemann, 1840 from Wulff Land and Peel \& Christie (1982) and Peel et al. (1982) also recorded its occurrence in the stratigraphically equivalent Humboldt Formation of western North Greenland and the Dallas Bugt Formation of Inglefield Land.

The present material comprises seven collections, each carrying a Geological Survey of Greenland collection number (GGU prefix, Grønlands Geologiske Undersøgelse). Figured specimens also bear a specimen number prefixed by MGUH and are housed in the Geological Museum, University of Copenhagen. In view of the limited amount of available material, the trace fossils are not described using any rigorous or formal taxonomic treatment. Rather, brief descriptions are given of the trace fossils present in individual sam- 




Fig. 1. Distribution of the Buen Formation in North Greenland and geographic location of localities 1 and 2 as discussed in the text.

ples, which are discussed stratigraphically. Examples of all ichnotaxa are figured for future comparative purposes.

\section{Stratigraphy}

Cambrian shelf stratigraphy in North Greenland is reviewed by Peel (1982) and Higgins et al. (in press a, b), and described in detail by Ineson \& Peel (in press). In southern areas of central North Greenland, carbonates of the Portfjeld Formation unconformably overlie Proterozoic clastics and carbonates. The formation yields spirally coiled cyanobacteria suggestive of an early Cambrian age (Peel, 1988) but fossils capable of providing a more precise age are lacking. Siliciclastic sediments of the overlying Buen Formation have yielded nevadiid trilobites near the base of the forma- tion in northern Peary Land, in association with a diverse assemblage of poorly skeletised fossils (Conway Morris et al., 1987; Blaker, 1988). Olenellids (Poulsen, 1974) and an undescribed nevadiid (J. S. Peel, personal communication, 1989) occur in the upper part of the formation in southern Peary Land, indicating that the Buen Formation is of middle to late Early Cambrian in age. Overlying carbonates and siliciclastics of the $\mathrm{Br} ø$ lund Fjord and Tavsens Iskappe Groups yield trilobitedominated faunas of late Early Cambrian to earliest Ordovician age.

At locality 1 , in the land area south of Nares Land (fig. 1), the Buen Formation comprises cross-bedded glauconitic sandstones interbedded with thinly bedded sandstones, siltstones and shales which pass upwards into siltstones and shales (fig. 2). Detailed palaeo-environmental interpretation of the succession is beyond the 


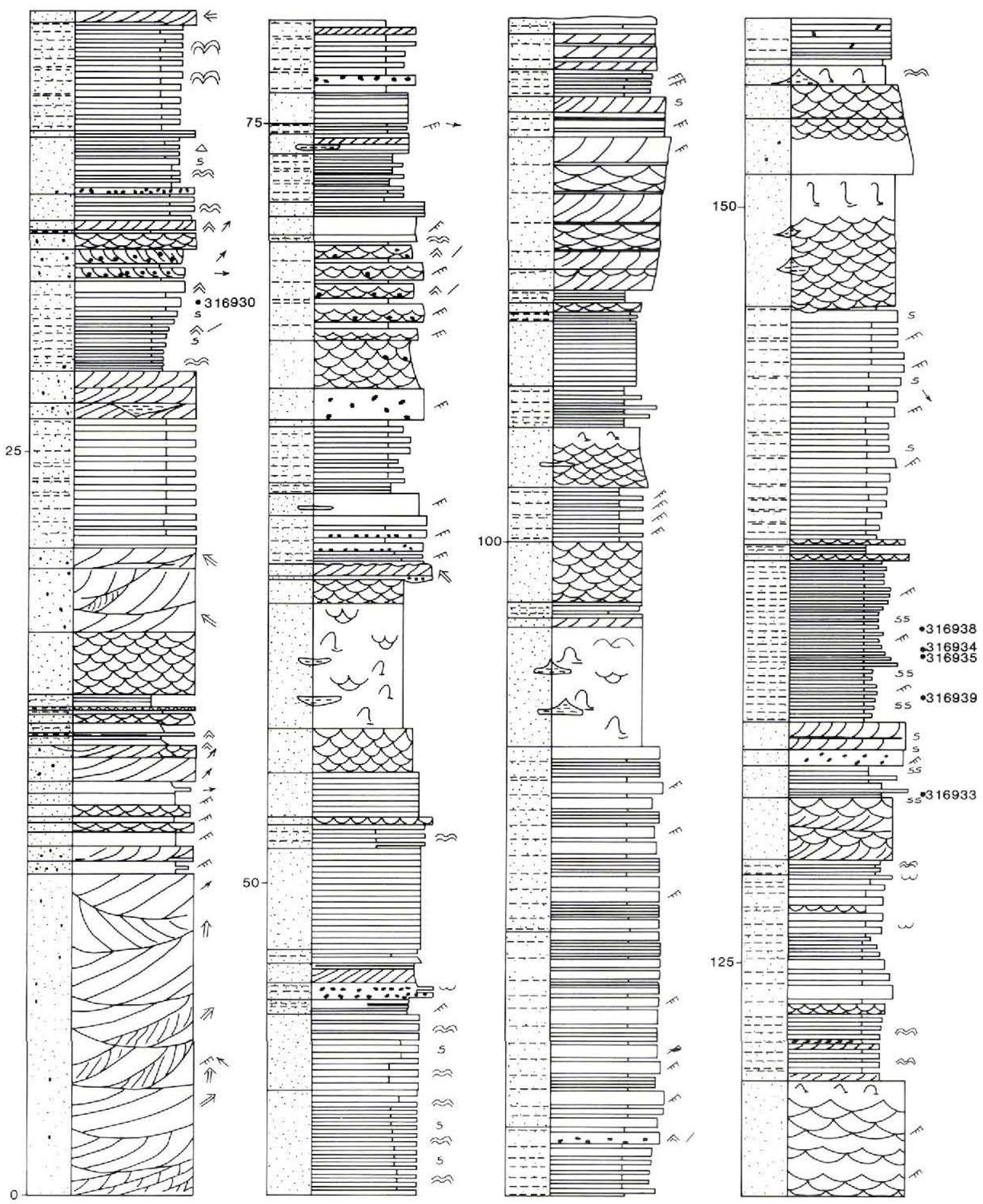

scope of this manuscript. Nevertheless, the overall fining-upward succession is interpreted to represent tidal and storm-dominated deposition in a shallow marine shelf environment during the Early Cambrian trans- gression of the North Greenland platform (I. D. Bryant and J. R. Ineson, unpublished information).

Almost all the collections described here were made from a $250 \mathrm{~m}$ long section recorded from fresh expo- 



Fig. 2. Section through part of the Buen Formation, measured in an unnamed land area south of Nares Land (fig. 1, locality 1). The base of the section is located 1-2 $\mathrm{m}$ above the base of the formation. Samples discussed in the text are indicated by GGU collection numbers.

sures adjacent to an unnamed glacier in an unnamed land area south of Nares Land (fig. 1, locality 1). This section (fig. 2) afforded the opportunity to log the strata bed by bed and to examine the contained ichnofaunas stratigraphically in vertical and bedding plane exposures. A single described specimen of the ichnogenus cf. Zoophycos Massalongo, 1855 was collected by J. S. Peel from an outcrop of the Buen Formation $150 \mathrm{~km}$ to the 
east, at the western end of $\emptyset$ vre Midsommers $\emptyset$, Peary Land (fig. 1, locality 2), where it occurs together with cf. Palaeobullia. This specimen is included within this report as the ichnogenus was not recognised in the main section under consideration; its presence obviously increases the overall diversity of the trace fossils within the Buen Formation.

\section{Ichnology}

Very few trace fossils are preserved in the lower part of the formation, presumably on account of the presence of predominant medium to coarse-grained crossbedded sandstones (fig. 2). Such sandstones were deposited from rapidly migrating bedforms in a high energy tide-dominated nearshore environment. Potential trace fossils, therefore, are unlikely to have been preserved even though the environment was possibly originally favourable to infaunal filter feeders. Additionally, substrate mobility possibly inhibited the settlement of filter feeders. The absence of traces produced by deposit-feeding organisms probably resulted from the lack of exploitable organic-rich muds; the paucity of such muds would also have precluded toponomic preservation of potential trace fossils. The only structures of probable biogenic origin observed on several upper surfaces of these sandstone units consist of $\mathbf{1 0}$ to $\mathbf{2 0} \mathrm{mm}$ diameter circular mottles, strongly resembling structures described as 'terriers auréolés' by Gaillard (1984). In plan view these structures comprise a circular orange-brown core (1-2 $\mathrm{mm}$ in diameter) surrounded by either: (1) a paler-coloured ring that is in turn surrounded by a thin (1-2 mm wide) orange-brown ring, or (2) wider concentric rings of alternating green and brown sandstone. In longitudinal section these zones form vertical rod-like structures of variable length, commonly with a grain size contrast between the core (coarser) and the surrounding sediment. The concentric layering of these structures is not considered a primary feature as, for example, in the ichnogenus Cylindrichnus Toots in Howard, 1966 but rather is interpreted as a result of variable diagenetic alteration of Skolithos Haldemann, 1840 burrows infilled with glauconite-rich sandstone.

Unlike the cross-bedded sandstone facies, thinly interbedded (heterolithic) sandstone, siltstone and shale lithofacies contain the majority of observed trace fossils. Heterolithic facies occur as 3-14 m thick upwardcoarsening and thickening packages.

GGU collection 316930 was made $30 \mathrm{~m}$ above the base of the formation in the first such heterolithic package above the basal sandstones (fig. 2). The sample comprises a thin layer of medium-grained sandstone with mudstone intraclasts which grades upwards into massive to ripple-laminated, glauconitic and micaceous sandstone. The undersurface of the bed preserves a polygonal network of ridges, probably as a result of synaeresis although an origin as desiccation cracks cannot be ruled out. Evidence of biogenic activity is present on the upper surface, which possesses gently curving, internally structureless, smooth epichnial unbranched ridges that vary between 4 and $9 \mathrm{~mm}$ in diameter and are of variable length. In section the ridges are seen to result from flattened tubes running sub-horizontally through the sediment; their variable thickness in plan view results from their varying intersection with the bedding plane. Burrow fill is similar in grain size to the enclosing sediment. We are reluctant to formally name these structures; they closely resemble Palaeophycus Hall, 1847 but this ichnogenus, according to Pemberton \& Frey (1982), is distinctly lined, and the burrows here possess no such linings. They also resemble Planolites Nicholson, 1873 which does not possess burrow linings, but possesses a fill of different grain size from the host rock (Pemberton \& Frey, 1982). The structures are not figured, in view of the uncertainty in identification, though similar traces can be observed in association with Psammichnites Torell, 1870 as figured herein (fig. 7), where they are preserved as epichnial grooves and not ridges.

GGU collection 316933 was made higher within the sequence $(130.4 \mathrm{~m})$ and comprises parallel-laminated, poorly sorted, fine to medium-grained, glauconite-rich sandstone. Both upper and lower surfaces exhibit crosscutting, virtually straight Palaeophycus tubularis Hall, 1847 , up to $11 \mathrm{~mm}$ in diameter, of variable length, with a burrow fill lithologically similar to the host rock. A possible Skolithos Haldemann, 1840 is also present.

By far the most abundant trace fossils from the section occur between $133 \mathrm{~m}$ and $147 \mathrm{~m}$ (fig. 2) on and within heterolithic beds of fine to coarse-grained, ripple-laminated and parallel-laminated sandstones interlayered on a centimetre scale with silty shales and shales. The remaining collections described here from locality 1 were made from this part of the sequence.

The lowermost collection, GGU 316939, was made in ripple-laminated, ripple-marked fine-grained sandstones and contains Cruziana cf. C. stromnessi (Trewin, 1976), Hormosiroidea Schaffer, 1928, Monomorphichnus cf. M. bilinearis Crimes, 1970, Palaeophycus tubularis Hall, 1847 and Phycodes pedum Seilacher, 1955.

Cruziana cf. C. stromnessi (fig. 3) is preserved in convex hyporelief and consists of bilobed structures, which may cross-cut, up to $17 \mathrm{~cm}$ in length, more typically shorter, and commonly 0.7 to $0.8 \mathrm{~mm}$ in width (fig. 3). Individual traces possess moderately impressed lobes with transverse and variably but typically weakly 


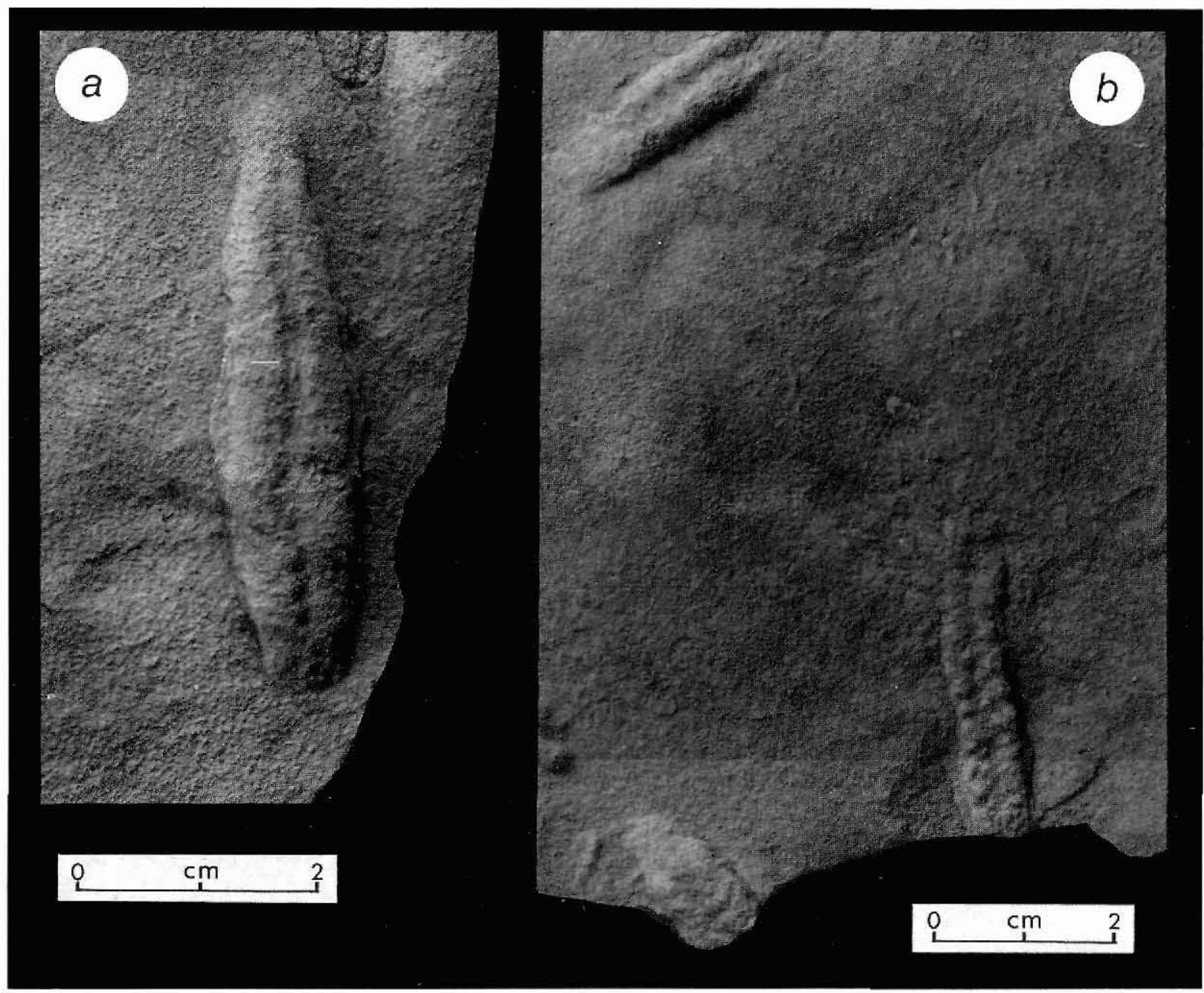

Fig. 3. Cruziana cf. C. stromnessi (Trewin, 1976) from GGU collection 316939. a is MGUH 19.639 and b is MGUH 19.640. Preservation is in convex hyporelief.

developed scratches or knobs which extend from the axial furrow to the margins of the lobes. Rare examples are smooth. The median furrow is clearly defined but less deeply impressed than the lobes. A single canoeshaped example (fig. 3a) attains a maximum width of $12.5 \mathrm{~mm}$, which is unusual for an ichnospecies typically less than 5 or $6 \mathrm{~mm}$ in width (Fillion \& Pickerill, 1990).

Hormosiroidea isp. (fig. 4; GGU collection 316939) is preserved in concave epirelief as a series of curved to slightly meandering disconnected dimples, 1 to $2 \mathrm{~mm}$ in width and length and separated by 2 to $5 \mathrm{~mm}$ of undisturbed sediment (fig. 4a). In convex hyporelief the specimens form a series of disconnected or more rarely connected pods of sediment; individual pods are 1 to 3 $\mathrm{mm}$ wide and up to $15 \mathrm{~mm}$ in length but typically shorter (fig. 4b). As noted by Crimes \& Anderson (1985) the type ichnospecies $H$. florentina Schaffer, 1928, as fig- ured in Häntzschel (1975, p. W69, fig. 43.3), is the only ichnospecies of Hormosiroidea in which the knobs or pods are connected by a narrow thread of sediment. Crimes \& Anderson (1985) therefore suggested two possible alternatives for the mode of production of their new ichnospecies $H$. canadensis Crimes \& Anderson, 1985. In the first, tight vertical meanders were arranged in a plane running through the line of burrows, while in their second alternative a lower master burrow had vertical feeders. The material here suggests the former alternative to be more plausible. In view of the limited material (two examples) the trace is only identified at the ichnogeneric level. The samples preserved in hyporelief somewhat resemble Tuberculichnus Książkiewicz, 1977. However, according to the interpretation of Książkiewicz (1977), the pods in this ichnogenus are not connected so that there is no epirelief equivalent and, 







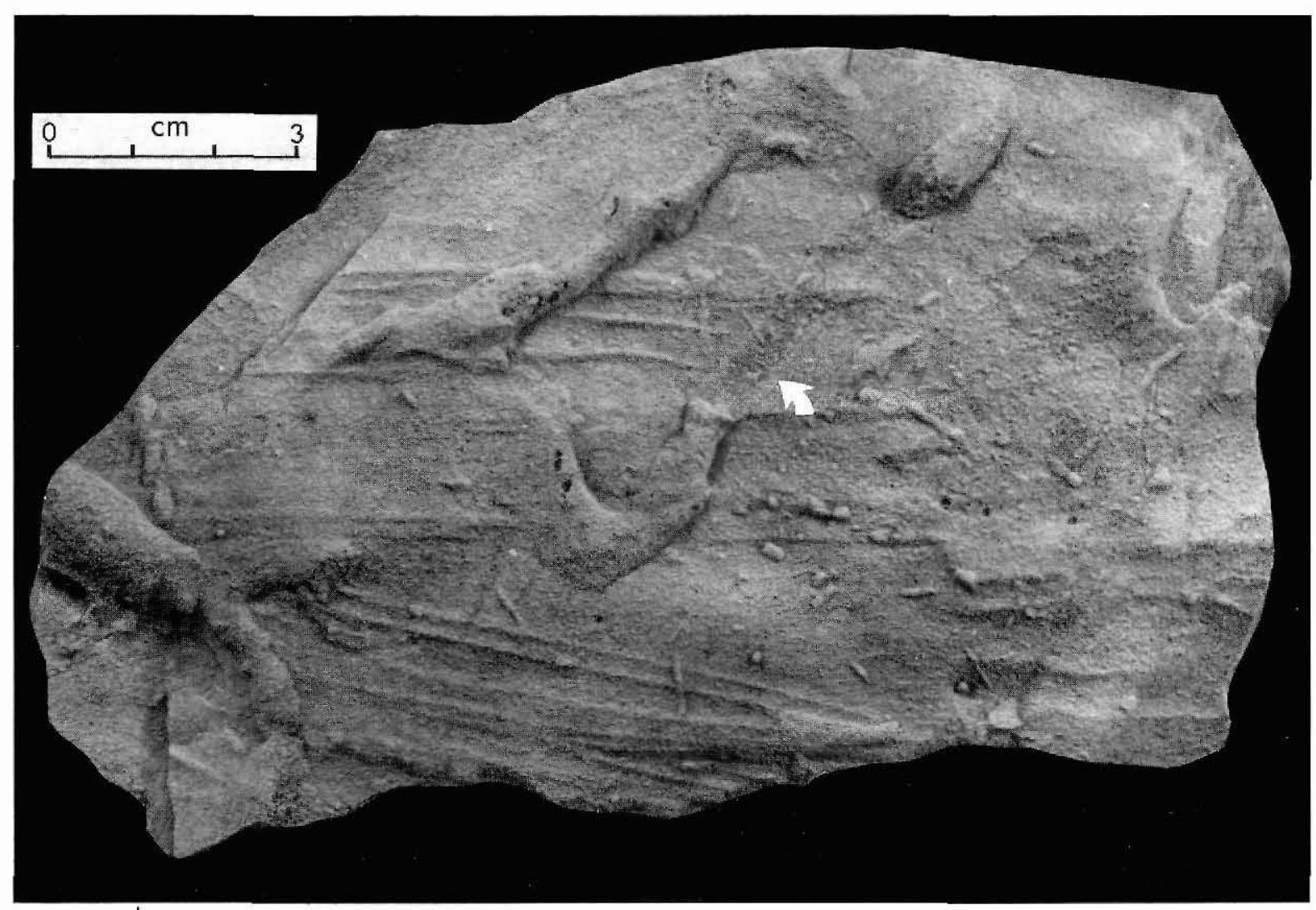

Fig. 5. Monomorphichnus ef. M. bilinearis Crimes, 1970; MGUH 19.642 and Palaeophycus tubularis Hall, 1847; MGUH 19.643 from GGU collection 316939. Preservation is in convex hyporelief on a sandstone sole. Note the thin lining (arrowed), within $P$. tubularis, which clearly post-dates Monomorphichnus cf. M. bilinearis.

additionally, this ichnogenus is apparently restricted to flysch deposits. They also resemble Neonereites Seilacher, 1960 figured by Fritz \& Crimes (1985, Plate 3F, p. 10) from the Lower Cambrian of British Columbia, though this specimen does not appear to be a convincing example of Neonereites as it does not possess the juxtaposed or closely connected pods or pustules of sediment typical of this ichnogenus (see Häntzschel, 1975).

Monomorphichnus cf. M. bilinearis (fig. 5; GGU collection 316939) is preserved in convex hyporelief and consists of straight to gently curved and paired parallel striae each approximately $1 \mathrm{~mm}$ wide and up to $7 \mathrm{~cm}$ in length. Individual striae within a set are commonly equally, more rarely unequally, impressed and separated by 1 to $2 \mathrm{~mm}$ of undisturbed sediment. Ichnospecific assignment to Monomorphichnus cf. M. bilinearis is only tentative because according to Crimes (1970) one stria within a set is typically more deeply impressed than the other, a feature that is uncommon in the material here. Otherwise, the material is identical to $M$. bilinearis and clearly differs from other ichnospecies of Monomorphichnus.

Palaeophycus tubularis (fig. 5; GGU collection 316939 ) is preserved in convex hyporelief and consists of straight to gently curved to slightly tortuous, unornamented, horizontal, thinly lined burrows up to $1 \mathrm{~cm}$ in diameter and $8 \mathrm{~cm}$ in length, with a burrow fill of similar grain size to the enclosing sediment (fig. 5). A more detailed discussion of this ichnospecies may be found in Pemberton \& Frey (1982).

Phycodes pedum (fig. 6; GGU collection 316939) is preserved in convex hyporelief. It consists of straight, curved or looping, smooth burrow systems, each consisting of a main branch that bifurcates at short intervals to give minor branches; these are falcate and pass around the main burrow and then upwards into the

Fig. 4. Hormosiroidea isp.; MGUH 19.641 from GGU collection 316939. a is the upper surface expression where preservation is in concave epirelief and $\mathrm{b}$ is the sole of the same specimen where preservation is in convex hyporelief. 





sandstone. The minor branches are typically developed sinistrally within an individual burrow though smaller portions of individual systems may exhibit alternating dextral and sinistral branches (fig. 6) similar to those observed in the ichnogenus Treptichnus Miller, 1889. Individual systems vary in width from 1 to $8 \mathrm{~mm}$, the width being constant within each system, and in length up to a maximum observed $21 \mathrm{~cm}$. Associated markings on the sole of the sandstone containing $P$. pedum may be inorganic or produced by limbs of arthropods (see fig. 6b).

Collection GGU 316935 was made almost $1 \mathrm{~m}$ higher in the section than GGU 316939, described above, and preserves a single example and a portion of a second of the ichnogenus Psammichnites Torell, 1870, together with straight to curved epichnial grooves (see previous discussion of collection GGU 316930). Psammichnites (fig. 7; GGU collection 316935) is preserved in positive epirelief on the upper surface of a fine to mediumgrained, parallel-laminated sandstone. The better-preserved example consists of a $24 \mathrm{~cm}$ long bilobed trace, 2.3 to $3.2 \mathrm{~cm}$ in width and 3 to $4 \mathrm{~mm}$ in height, which follows a straight to gently curving course (fig. 7). Individual lobes are smooth with steep outer margins which are slightly sinuous but clearly defined. Though typically smooth, a lobe at one end of the specimen exhibits evidence of imbricated pads of sediment (fig. 7b). Each lobe is separated by an axial furrow, 3 to $4 \mathrm{~mm}$ in width and up to $5 \mathrm{~mm}$ in depth and possessing a silty mudstone infill. The transverse cross-sectional shape is approximately $\mathrm{m}$-shaped. The longitudinal profile is slightly asymmetric as a result of alternating more elevated and more deeply impressed portions of the trace, similar to specimens of $P$. gigas Torell, 1870 recently described from the Lower Cambrian of New Brunswick, Canada, by Hofmann \& Patel (1989). Though we assign this specimen to Psammichnites, we are reluctant to designate an ichnospecific name in view of the fact that its ichnospecies are in need of serious taxonomic revision. In addition, the present material is limited and, perhaps more importantly, it is still not clear whether or not Torell's (1870) material is preserved in epirelief or hyporelief (for discussion see Fillion \& Pickerill, 1990). As such, Psammichnites may represent the senior synonym of Olivellites Fenton \& Fenton, 1937 and possibly Laminites Ghent \& Henderson, 1966. However, it differs (cf. D'Alessandro \& Bromley, 1987) from Aulichnites Fenton \& Fenton, 1937 which does not possess a laminated fill, according to Hofmann \& Patel (1989) and Fillion \& Pickerill (1990), nor a well-developed median groove (see also Hakes, 1977, p. 218), is narrower, more winding and possesses distinct lateral furrows. The presence of a laminated fill in the specimen described here cannot be unambiguously ascertained; nevertheless, deflection of laminae below the lobes downwards towards the central axial furrow can be observed at one end of the specimen, suggesting this to be the case. The structure of the trace is consistent with an organism (?mollusc) moving through the sediment just below the sedimentwater interface, thereby forming the median groove, displacing sediment to either side and allowing some sediment to collapse back into the groove after its passage. The second specimen consists of a small portion of a single lobe (fig. 7a) and is not worthy of description.

GGU collection 316934 was made $0.9 \mathrm{~m}$ higher in the sequence from a glauconite-rich, parallel-laminated, fine to medium-grained sandstone (fig. 2). The lower surface possesses Palaeophycus preserved in convex hyporelief similar to examples already described and also possible arthropod scratch traces. The upper surface of the specimen exhibits narrow, short and unnamed epichnial grooves and ridges, along with evidence of primary current lineation and trace fossils tentatively identified here as cf. Palaeobullia Götzinger \& Becker, 1932 (sensu Miller \& Knox, 1985) (figs 8, 9). The traces comprise a series of gently curved to irregularly meandering to looping and intersecting irregularly preserved epichnial grooves, $1 \mathrm{~cm}$ in diameter and of variable length. The grooves are only slightly impressed, Ushaped and flanked by variably and irregularly developed epichnial ridges, which in some instances assume an almost lobate appearance (fig. 8). Weakly developed transverse ornament within the grooves is apparent in places, but only rarely as they are more typically smooth. The flanking ridges vary in width from 1 to 3 $\mathrm{mm}$.

The traces are only tentatively identified as Palaeobullia as they are generally nondescript furrows. This is typical of Palaeobullia, however, when preserved as concave epireliefs (Miller \& Knox, 1985). More typically, the ichnogenus, which Häntzschel (1975, p. 106) assigned to the morphologically variable 'Scolicia group', possesses a well-developed median axis and variably developed transverse ornamentation. However, as discussed in detail by Knox \& Miller (1985), the presence or absence of these features is a reflection of

Fig. 6. Phycodes pedum Seilacher, 1955.; MGUH 19.644 (arrowed) from GGU collection 316939. a is a view of virtually the complete slab and $\mathbf{b}$ is an enlargement of the upper central-left portion. Note that although the minor branches are typically developed in a sinistral manner, some specimens develop a Treptichnus-like branching pattern. Smaller arrow denotes possible arthropod scratch marks. Preservation is in convex hyporelief on a sandstone sole. 

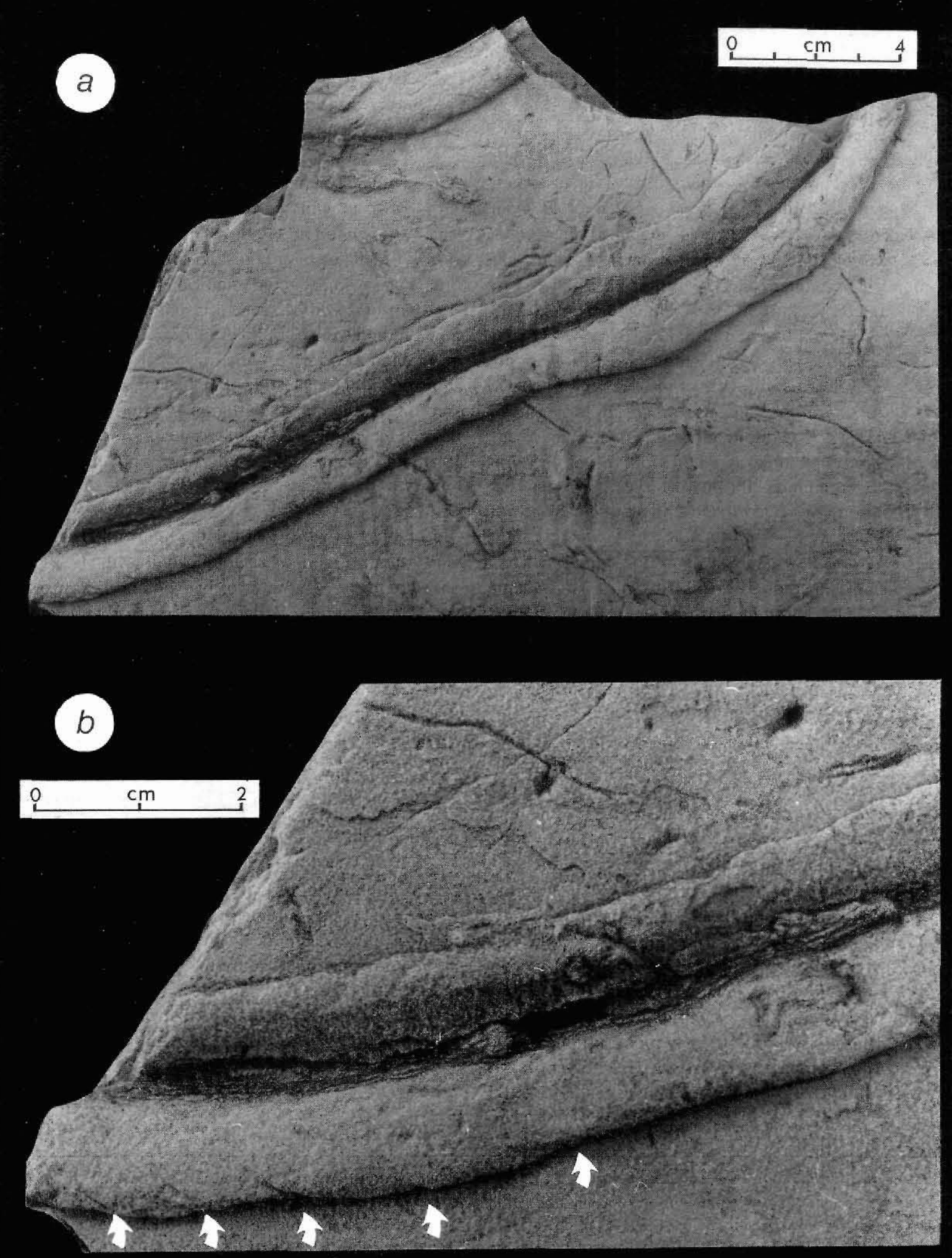


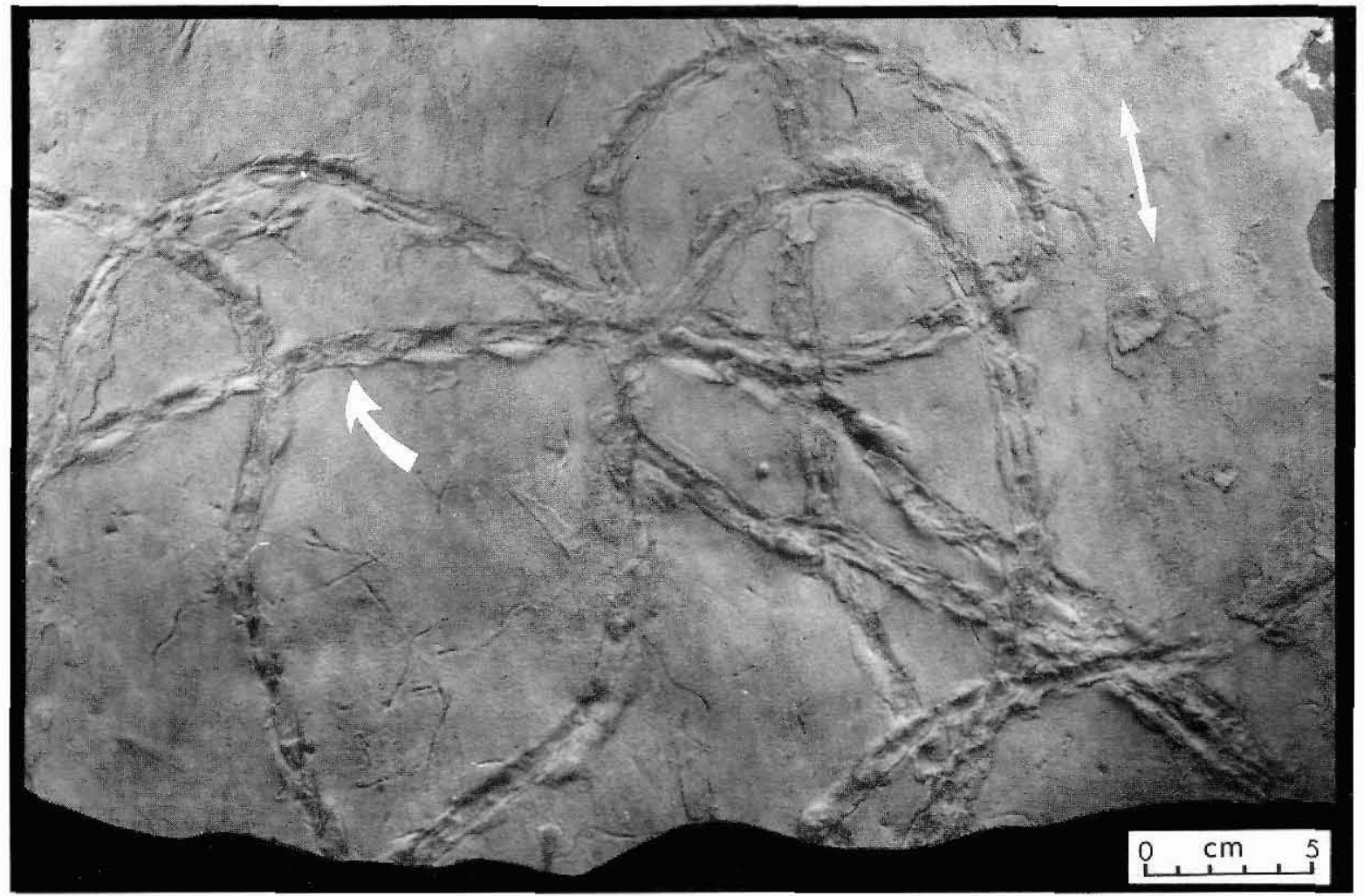

Fig. 8. cf. Palaeobullia isp.; MGUH 19.646 from GGU collection 316934. Preservation is in concave epirelief on upper, current-lineated (arrowed) surface of a sandstone layer. Note the almost lobe-like appearance of the outer ridges in one section of the trace (arrowed).

substrate consistency at the time of production by the organism when moving across the sediment surface, and indeed, such features may or may not be present.

Morphologically similar, though not identical, traces have been observed from the Buen Formation $150 \mathrm{~km}$ to the east at the western end of $\emptyset_{\mathrm{v} r e}$ Midsommers $\emptyset$, Peary Land, from approximately $50 \mathrm{~m}$ above its base (J. S. Peel, personal communication, 1989; see fig. 9) and from the Dividal Group of arctic Norway (R. G. Bromley, personal communication, 1989).

Slightly less than $0.5 \mathrm{~m}$ higher in the section a specimen representing collection GGU 316938 was made within parallel-laminated, fine-grained sandstone (fig. 2). The sole of this specimen possesses several unidentifiable biogenic structures in addition to the following ichnotaxa: Curvolithus Fritsch, 1908, Monomorphichnus lineatus Crimes et al., 1977, Palaeophycus tu- bularis Hall, 1847, Rusophycus Hall, 1852 and Skolithos Haldemann, 1840. These are all illustrated in fig. 10.

Curvolithus isp. (fig. 10) consists of a curved trilobed trace, $0.63 \mathrm{~cm}$ wide and $2.6 \mathrm{~cm}$ in length, composed of a smooth central flattened area separated by very narrow angular furrows from sharp and clearly defined marginal ridges, each approximately just less than $1 \mathrm{~mm}$ in width. The trace is smooth, lacking any ornamentation. The ichnogenus Curvolithus is one that exhibits considerable variation in form and preservational characteristics (e.g., see Heinberg, 1970, 1973) and is a candidate for detailed taxonomic revision (Fillion \& Pickerill, 1990). The unsatisfactory taxonomic status and the fact that only a single and small incomplete specimen is present in GGU collection 316938 precludes any ichnospecific assignment.

Monomorphichnus lineatus (fig. 10) is also present as

Fig. 7. Psammichnites isp.; MGUH 19.645 from GGU collection 316935. Preservation is in convex epirelief on the upper surface of a sandstone layer; a exhibits the complete specimen and an incomplete portion of a single lobe at its top and $b$ is an enlargement of the lower left segment as observed in a. Note the m-shaped cross-section, the steep outer margins and the imbricated sediment pads developed in one of the lobes (arrowed). 


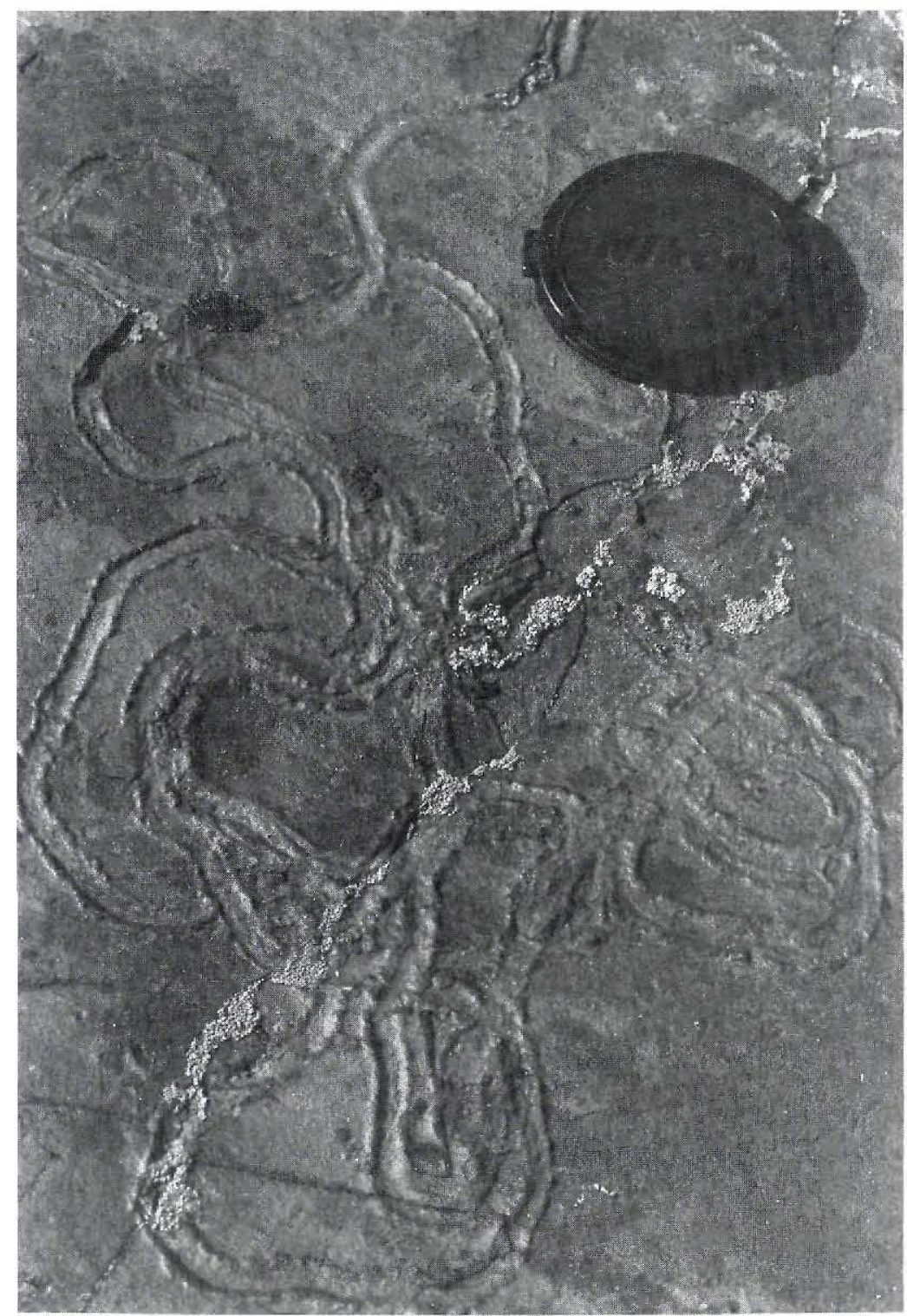

Fig, 9. Field photograph (courtesy of J. S. Peel) of cf. Palaeobullia from the Buen Formation at the western end of $\emptyset$ vre Midsommers $\varnothing$, Peary Land, preserved in concave epirelief. Lens hood is approximately $5 \mathrm{~cm}$ in diameter. a single specimen, consisting of a single set of five isolated, straight to slightly curved ridges preserved in positive hyporelief. The ridges are more or less equally spaced, each being approximately $18 \mathrm{~mm}$ in length and the entire set is approximately $22 \mathrm{~mm}$ wide. A detailed discussion of the ichnogenus Monomorphichnus Crimes, 1970 has recently been given in Fillion \& Pickerill (1990).

Palaeophycus tubularis (fig. 10) is present as a series of straight, curved to slightly tortuous burrows, 2 to 6 $\mathrm{mm}$ in width, of variable length, parallel or sub-parallel to stratification and preserved in positive hyporelief. An extremely thin silty mudstone lining contrasts markedly with the fine-grained sandstone infill, which is similar in grain size to the host rock. The burrows intersect, giving the impression of branching; otherwise, they are unbranched.

Rusophycus (fig. 10) is present as a single poorly preserved and a single moderately preserved specimen, both in convex hyporelief. The best example (fig. 10-4,

Fig. 10. Sandstone sole representing GGU collection 316938. Preserved here are 1. Curvolithus isp., MGUH 19.647, 2. Monomorphichnus lineatus Crimes et al., 1977. MGUH 19.648, 3. Palaeophycus tubularis Hall, 1847. MGUH 19.649, 4. Rusophycus isp., MGUH 19.650 (upper right) and MGUH 19.651 and 5. Skolithos isp.. MGUH 19.652. 





below the scale) is an incomplete specimen, at least 49 $\mathrm{mm}$ in maximum width, and an incomplete length of 23 $\mathrm{mm}$. The specimen consists of two very shallowly impressed lobes, each possessing five or six more deeply impressed transverse scratch traces, which extend over the entire surface of the lobes. A single scratch is possibly bifid. The median furrow is unfortunately not preserved. The second specimen (fig. 10-4, upper right) is $28 \mathrm{~mm}$ wide, at least $26 \mathrm{~mm}$ long, and similarly possesses at least six transversely oriented scratch markings across the better defined lobe. This specimen has been subsequently cut by the Curvolithus burrow. Both examples are considered too poorly preserved for ichnospecific assignment. They are reminiscent of Rusophycus avalonensis Crimes \& Anderson, 1985, however, described from the Lower Cambrian of eastern Newfoundland by Crimes \& Anderson (1985) and Narbonne et al. (1987) in that this ichnospecies is shallowly impressed, of 30 to $50 \mathrm{~mm}$ in width, and commonly has transverse bundles of five or more scratches. Specimens figured by these authors do not bear resemblance, however, to the holotype of $R$. avalonensis (specimen GPIT 1392/6, see Seilacher, 1970, fig. 7.3) selected by Crimes \& Anderson (1985) and more closely resemble $R$. latus Webby, 1983 (Fillion \& Pickerill, 1990). Accordingly, the specimens here also resemble $R$. latus and a taxonomic reassessment of $R$. avalonensis seems necessary.

Skolithos (fig. 10) is observed as isolated cylindrical and vertical unlined tubes, up to $8 \mathrm{~mm}$ in diameter, intersecting the sandstone sole, with a structureless sandstone fill of similar grain size to the enclosing host rock. The lack of longitudinal sections precludes ichnospecific assignment (see Alpert, 1974).

GGU collection 316942 , the stratigraphically highest sample collected from this heterolithic sequence (fig. 2), comprises a ripple-laminated glauconitic sandstone with micaceous drapes. Trace fossils, possibly Palaeophycus tubularis, are preserved as straight to curved, isolated or cross-cutting hypichnial ridges, 1 to $5 \mathrm{~mm}$ in width, of variable length, and preserved in convex hyporelief.

Finally, as previously noted, a single specimen (fig. 11; GGU collection 271778) collected by J. S. Peel from approximately $50 \mathrm{~m}$ above the base of the Buen Formation at the western end of $\emptyset$ vre Midsommers $\emptyset$, Peary Land (fig. 1, locality 2), is also described herein. The specimen is an enigmatic penetrative plate-like spreiten structure preserved on and within a fine to mediumgrained sandstone. Its upper surface (fig. 11b) is $52 \mathrm{~mm}$ long, 3 to $6 \mathrm{~mm}$ wide and possesses lamellae composed of alternating light and dark sandstone. The lamellae are variably developed along the length, are moderately to strongly arcuate and may attain a density of six per centimetre. In vertical section the structure is sub-vertical to inclined $\left(c .45^{\circ}\right)$ and possesses a variably developed convex-upward spreite. The trace somewhat resembles Zoophycos Massalongo, 1855 to which it is tentatively referred pending the availability of additional material (R. G. Bromley, personal communication, 1989).

\section{Discussion and conclusions}

The eleven ichnogenera recorded and briefly described here represent the first trace fossils to be examined in any detail from the Buen Formation of central North Greenland apart from Rusophycus marginatus described previously by Bergström \& Peel (1988). The small amount of collected material and its rather variable preservation has generally precluded ichnospecific assignment of most specimens and, in some instances, even confident identification at the ichnogeneric level has proven impossible. We feel that additional sampling, particularly from different sections within the Buen Formation, would undoubtedly not only increase the overall diversity of traces contained within the sequence, but would also permit a more accurate taxonomic assessment of the material described herein. Nevertheless, the recorded assemblage compares favourably with other Lower Cambrian ichnoassemblages reported from both Greenland (Pickerill \& Peel, 1990) and elsewhere.

The Lower Cambrian Bastion Formation of NorthEast Greenland has also yielded the ichnogenera $\mathrm{Cru}$ ziana, Monomorphichnus, Palaeophycus, Phycodes, Psammichnites, Rusophycus and Skolithos (Pickerill \& Peel, 1990). Though Curvolithus, Hormosiroidea, cf. Palaeobullia and cf. Zoophycos have not been recorded from the Bastion Formation, this latter sequence contains a far more diverse ichnoassemblage, probably because of the much larger number of available and studied samples. With the exception of Palaeobullia, all of the recorded ichnogenera have previously been reported from Lower Cambrian strata (see Crimes, 1987 for review). It is perhaps understandable why Palaeobullia has not been reported, as it is a morphologically variable ichnogenus resembling several other arthro-

Fig. 11. Specimens of cf. Zoophycos isp.; a. is a field photograph from Øvre Midsommers $\varnothing$, Peary Land (courtesy of J. S. Peel). b, $c$, and d are various views of the same specimen (MGUH 19.653 from GGU collection 271778); b represents the upper surface expression and $\mathrm{c}$ and $\mathrm{d}$ lateral views. 

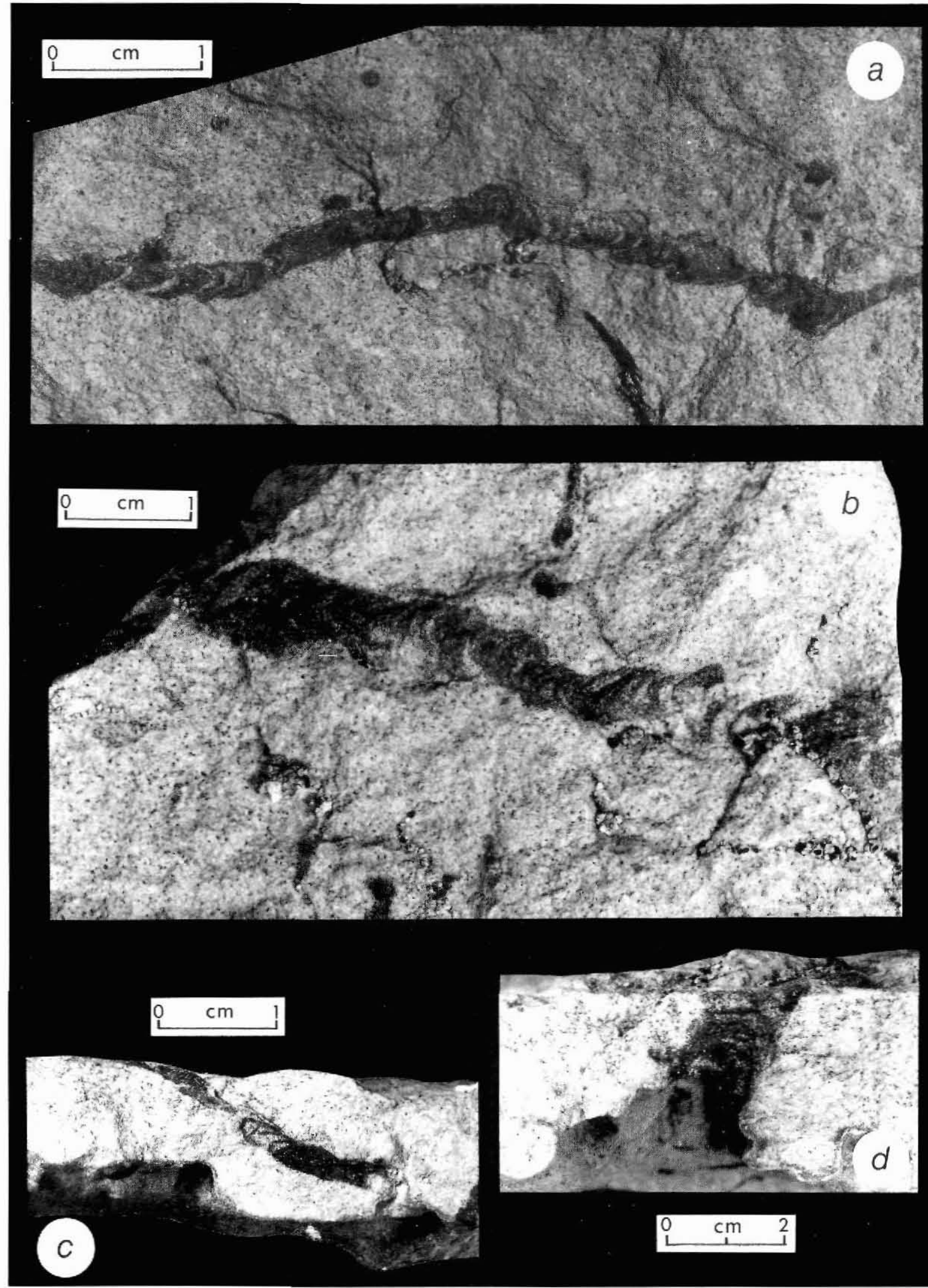
pod-produced traces (Knox \& Miller, 1985) and included in the 'Scolicia group' by Książkiewicz (1970) and Häntzschel (1975). Scolicia de Quatrefages, 1849 sensu lato has been recorded from many Lower Cambrian sequences (Crimes, 1987, and references therein).

The vertical distribution of the described trace fossils is clearly related to lithofacies. Thus, the essentially monolithologic cross-bedded sandstone lithofacies comprising the basal portion of the sequence has only yielded Skolithos and Palaeophycus. Possible reasons for the low diversity have previously been outlined. Interestingly, the absence of funnel-shaped tops to the Skolithos tubes (= Monocraterion Torell, 1870) possibly suggests a subtidal rather than intertidal origin for much of the cross-bedded lithofacies (cf. Barwis, 1985; I. D. Bryant and J. R. Ineson, unpublished information) or, alternatively, may be a result of truncation prior to deposition and stabilization of overlying sandstone sets (cf. Goodwin \& Anderson, 1974).

In contrast, heterolithologic sandstone, siltstone and shale lithofacies from higher in the sequence contain a moderately diverse ichnoassemblage, numerically dominated by dwelling (e.g. Palaeophycus) and foraging or feeding (e.g. Phycodes) structures. The influx of finergrained, particularly muddy material, and presumably a reflection of background lower energy conditions and more stable substrates, was undoubtedly conducive to exploitation by deposit-feeding organisms. Toponomic preservation of their activity was presumably enhanced by the availability of a variety of differing lithologies. Skolithos is comparatively rare in this part of the sequence compared to the cross-bedded sandstone lithofacies, suggesting a relatively inhospitable environment for infaunal filter feeders.

The heterolithic lithofacies are interpreted to have been deposited on low relief, shallow subtidal areas between tidal shoals, or on intertidal sand flats (I. D. Bryant and J. R. Ineson, unpublished information). Banks (1970), Crimes et al. (1977), Legg (1985) and Crimes \& Anderson (1985) have described similar lithofacies associations from similar environments from Lower Cambrian strata in, respectively, Finnmark, Spain and Newfoundland, and all of which contain comparable ichnocoenoses. Miller \& Knox (1985) recorded a moderately diverse trace fossil assemblage from interpreted tidal flat sequences in the Pennsylvanian of Tennessee. Using geological, present-day environmental and experimental data, Miller \& Knox (1985) and Knox \& Miller (1985) elegantly demonstrated that syndepositional sediment mass properties (particularly sediment consistency) varied between high and low tidal flat areas resulting in variable trace fossil morphologies. They demonstrated that generally uncompacted sedi- ment typical of lower tidal flat and shallow subtidal environments possessed biogenic structures of a different morphology and lacking fine details in comparison to upper tidal flats, characterised by firmer substrates, which possessed contrasting traces (but produced by the same organisms) that preserved fine morphological details (see also Pickerill et al., 1984, p. 435). A similar example of the importance of substrate consistency in the control of trace fossil morphology was given more recently by Clausen \& Vilhjálmsson (1986), from a Lower Cambrian sequence in Denmark. Indeed, at an even broader level, Ekdale (1985) has suggested that even ichnofacies are substrate controlled. Although the trace fossils described here are moderately well preserved, they do lack fine preservational details known from the same ichnogenera recorded in other sequences which possibly suggests that substrates in the heterolithic lithofacies were generally uncompacted and hence possibly of subtidal origin.

Acknowledgments. The material was collected during the summer of 1984 while I. D. B. was employed by the Geological Survey of Greenland. F. Sørensen is thanked for his help in logging the described section and collecting the material. J. S. Peel located the section, provided us with additional material from the Buen Formation, photographed the specimens and helped in the production of the manuscript. Technical assistance was provided by $R$. McCulloch, R. Northrup and D. Tabor of the University of New Brunswick. D. Fillion and R. G. Bromley read an early draught of the manuscript and for their constructive comments we are extremely grateful; use of isp. instead of ichnosp. as the standard abbreviation for ichnospecies follows the suggestion of R. G. Bromley.

\section{References}

Alpert, S. P. 1974: Systematic review of the genus Skolithos. J. Paleont. 48, 661-669.

Alpert, S. P. 1976: Trilobite and star-like trace fossils from the White-Inyo Mountains, California. J. Paleont. 50, 226-239.

Banks, N. L. 1970: Trace fossils from the late Precambrian and Lower Cambrian of Finnmark, Norway. In Crimes, T. P. \& Harper, J. C. (edit.) Trace fossils. Geol. J. Spec. Issue 3, 19-34. Liverpool: Seel House Press.

Barwis, J. H. 1985: Tubes of the modern polychaete Diopatra cuprea as current velocity indicators and as analogs for $S k o$ lithos - Monocraterion. In Curran, H. A. (edit.) Biogenic structures: their use in interpreting depositional environments. Soc. Econ. Paleont. Min., Spec. Pub. 35, 225-235.

Bergström, J. \& Peel, J. S. 1988: Lower Cambrian trace fossils from northern Greenland. Rapp. Grønlands geol. Unders. 137, 43-53. 
Blaker, M. R. 1988: A new genus of nevadiid trilobite from the Buen Formation (Early Cambrian) of Peary Land, central North Greenland. Rapp. Grønlands geol. Unders. 137, 33-41.

Clausen, C. K. \& Vilhjálmsson, M. 1986: Substrate control of Lower Cambrian trace fossils from Bornholm, Denmark. Palaeogeogr., Palaeoclimatol., Palaeoecol. 56, 51-68.

Conway Morris, S., Peel, J. S., Higgins, A. K., Soper, N. J. \& Davis, N. C. 1987: A Burgess Shale-like fauna from the Lower Cambrian of North Greenland. Nature 326, 181-183.

Cowie, J. W. \& Spencer, A. M. 1970: Trace fossils from the late Precambrian/Lower Cambrian of East Greenland. In Crimes, T. P. \& Harper, J. C. (edit.) Trace fossils. Geol. J. Spec. Issue 3, 91-100. Liverpool: Seel House Press.

Crimes, T. P. 1970: Trilobite tracks and other trace fossils from the Upper Cambrian of North Wales. Geol. J. 7, 47-68.

Crimes, T. P. 1987: Trace fossils and correlation of late Precambrian and early Cambrian strata. Geol. Mag. 124, 97119.

Crimes, T. P. \& Anderson, M. M. 1985: Trace fossils from late Precambrian - early Cambrian strata of southeastern Newfoundland (Canada): temporal and environmental implications. J. Paleont. 59, 310-343.

Crimes, T. P., Legg, I., Marcos, A. \& Arboleya, M. 1977: ?Late Precambrian - low Lower Cambrian trace fossils from Spain. In Crimes, T. P. \& Harper, J. C. (edit.) Trace fossils 2. Geol. J. Spec. Issue 9, 91-138. Liverpool: Seel House Press.

D'Alessandro, A. \& Bromley, R.G. 1987: Meniscate trace fossils and the Muensteria-Taenidium problem. Palaeontology 30, 743-763.

Ekdale, A. A. 1985: Paleoecology of the marine endobenthos. Palaeogeogr., Palaeoclimatol., Palaeoecol. 50, 63-81.

Fenton, C. L. \& Fenton, M. A. 1937a: Olivellites, a Pennsylvanian snail burrow. Am. Midl. Nat. 18, 452-453.

Fenton, C. L. \& Fenton, M. A. 1937b: Burrows and trails from Pennsylvanian rocks of Texas. Am. Midl. Nat. 18, 10791084.

Fillion, D. \& Pickerill, R. K. 1990: Ichnology of the Upper Cambrian(?) to Lower Ordovician Bell Island and Wabana groups of eastern Newfoundland. Palaeontogr. canadiana (in press).

Fritsch, A. 1908: Problematica Silurica. In Joachim Barrande, Systême Silurien du centre de la Bohême (separate), 28 pp. Prague: Publ. from Barrande Fund by author and editor.

Fritz, W. H. \& Crimes, T. P. 1985: Lithology, trace fossils and correlation of Precambrian-Cambrian boundary beds, Cassiar Mountains, north-central British Columbia, Canada. Geol. Surv. Canada Paper 83-13, 24 pp.

Gaillard, C. 1984: Bioturbation des sédiments pélagiques du Crétacé inférieur dans le bassin Vocontien (Chaînes subalpines mérionales, France). Geobios, Mém. Spécial 8, 205214

Ghent, E. D. \& Henderson, R. A. 1966: Petrology, sedimentation and paleontology of Middle Miocene graded sandstones and mudstone, Kaiti Beach, Gisborne. Trans. Roy. Soc. N.Z., Geol. 4, 147-169.

Goodwin, P. W. \& Anderson, E. J. 1974: Associated physical and biogenic structures in environmental subdivision of a Cambrian tidal sand body. J. Geol. 82, 779-794.

Götzinger, G. \& Becker, H. 1932: Zur geologischen Gliederung des Wienerwaldflysches (Neue Fossilfunde). Geol. Bund. Wien Jahrb. 82, 343-396.

Hakes, W. G. 1977: Trace fossils in Late Pennsylvanian cyclothems, Kansas. In Crimes, T. P. \& Harper, J. C. (edit.) Trace fossils 2. Geol. J. Spec. Issue 9, 209-226. Liverpool: Seel House Press.

Haldeman, S. S. 1840: Supplement to number one of 'A monograph of the Limniades, and other freshwater univalve shells of North America', containing descriptions of apparently new animals in different classes and the names and characters of the subgenera in Paludina and Anculosa, 3 pp. Philadelphia: J. Dobson.

Hall, J. 1847: Palaeontology of New York, Volume I. Containing descriptions of the organic remains of the Lower Division of the New York System, (equivalent of the Lower Silurian rocks of Europe). 338 pp. Albany: C. Van Benthuysen.

Hall, J. 1852: Palaeontology of New York, Volume II. Containing descriptions of the organic remains of the Lower Middle Division of the New York System (equivalent in part to the Middle Silurian rocks of Europe). 362 pp. Albany: C. Van Benthuysen.

Häntzschel, W. 1975: Trace fossils and problematica. In Teichert, C. (edit.) Treatise on Invertebrate Paleontology W. Miscellanea, Supplement 1, 269 pp. Lawrence: Geol. Soc. Am. and Kansas Univ. Press.

Heer, O. 1876-1877: Flora Fossils Helvetiae. Die vorweltliche Flora der Schweitz. 182 pp. Zurich: J. Würster \& Co.

Heinberg, C. 1970: Some Jurassic trace fossils from Jameson Land (East Greenland). In Crimes, T. P. \& Harper, J. C. (edit.) Trace fossils. Geol. J. Spec. Issue 3, 227-234. Liverpool: Seel House Press.

Heinberg, C. 1973: The internal structure of the trace fossils Gyrochorte and Curvolithus. Lethaia 6, 227-238.

Higgins, A. K., Ineson, J. R., Peel, J. S., Surlyk, F. \& Sønderholm, M. in press a: Cambrian to Silurian basin development, North Greenland. In Trettin, H. P. (edit.) The Innuitian region. The Geology of North America E. Ottawa: Geol. Surv. Canada.

Higgins, A. K., Ineson, J. R., Peel, J. S., Surlyk, F. \& Sønderholm, M. in press b: Lower Palaeozoic Franklinian Basin of North Greenland. Bull. Grønlands geol. Unders.

Hofmann, H. J. \& Patel, I. M. 1989: Trace fossils from the type 'Etcheminian Series' (Lower Cambrian Ratcliffe Brook Formation), Saint John area, New Brunswick, Canada. Geol. Mag. 126, 139-159.

Howard, J. D. 1966: Characteristic trace fossils in Upper Cretaceous sandstones of the Book Cliffs and Wasatch Plateau. Utah Geol. Mineral. Surv., Central Utah, Coal Bull. 80, 35-53.

Hurst, J. M. \& Peel, J. S. 1979: Late Proterozoic? to Silurian stratigraphy of southern Wulff Land, North Greenland. Rapp. Gronlands geol. Unders. 91, 37-56.

Ineson, J. R. \& Peel, J. S. in press: Cambrian shelf stratigraphy of North Greenland. Bull. Grønlands geol. Unders.

Knox, L. W. \& Miller, M. F. 1985: Environmental controls of 
trace fossil morphology. In Curran, H. A. (edit.) Biogenic structures: their use in interpreting depositional environments. Soc. Econ. Paleont. Min., Spec. Pub. 35, 167-176.

Książkiewicz, M. 1970: Observations on the ichnofauna of the Polish Carpathians. In Crimes, T. P. \& Harper, J. C. (edit.) Trace fossils. Geol. J. Spec. Issue 3, 283-322. Liverpool: Seel House Press.

Książkiewicz, M. 1977: Trace fossils in the flysch of the Polish Carpathians. Palaeontogr. pol. 36, 208 pp.

Legg, I. C. 1985: Trace fossils from a Middle Cambrian deltaic sequence, north Spain. In Curran, H. A. (edit.) Biogenic structures; their use in interpreting depositional environments. Soc. Econ. Paleont. Min., Spec. Pub. 35, 151-165.

Massalongo, A. B. 1855: Zoophycos: novum genus plantasum fossilium. 52 pp. Verona: Antonelli.

Miller, M. F. \& Knox, L. W. 1985: Biogenic structures and depositional environments of a Lower Pennsylvanian coalbearing sequence, northern Cumberland Plateau, Tennessee, U.S.A. In Curran, H. A. (edit.) Biogenic structures: their use in interpreting depositional environments. Soc. Econ. Paleont. Min. Spec. Pub. 35, 67-97.

Miller, S. A. 1889: North American geology and palaeontology for the use of amateurs, students and scientists. $664 \mathrm{pp}$. Cincinnati: Western Methodist Book Concern.

Narbonne, G. M., Myrow, P. M., Landing, E. \& Anderson, M. M. 1987: A candidate stratotype for the PrecambrianCambrian boundary, Fortune Head, Burin Peninsula, southeastern Newfoundland. Can. J. Earth Sci. 24, 1277-1293.

Nicholson, H. A. 1873: Contributions to the study of the errant annelides of the older Paleozoic rocks. Proc. Roy. Soc. Lond. 21, 288-290 (also Geol. Mag. 10, 309-310).

Peel, J. S. 1982: The Lower Palaeozoic of Greenland. In Embry, A. F. \& Balkwill, H. R. (edit.) Arctic geology and geophysics. Mem. Can. Soc. Petrol. Geol. 8, 309-330.

Peel, J. S. 1988: Spirellus and related helically coiled microfossils (cyanobacteria) from the Lower Cambrian of North Greenland. Rapp. Grønlands geol. Unders. 137, 5-32.

Peel, J. S. \& Christie, R. L. 1982: Cambrian-Ordovician platform stratigraphy: correlations around Kane Basin. In Dawes, P. R. \& Kerr, J. W. (edit.) Nares Strait and the drift of Greenland: a conflict in plate tectonics. Meddr Grønland Geosci. 8, 117-135.

Peel, J. S., Dawes, P. R., Collinson, J. D. \& Christie, R. L. 1982: Proterozoic - basal Cambrian stratigraphy across
Nares Strait: correlation between Inglefield Land and the Bache Peninsula. In Dawes, P. R. \& Kerr, J. W. (edit.) Nares Strait and the drift of Greenland: a conflict in plate tectonics. Meddr Grønland Geosci. 8, 105-115.

Pemberton, S. G. \& Frey, R. W. 1982: Trace fossil nomenclature and the Planolites-Palaeophycus dilemma. J. Paleont. 56, 843-881.

Pickerill, R. K. \& Peel, J. S. 1990: Trace fossils from the Lower Cambrian Bastion Formation of eastern Greenland. Rapp. Grønlands geol. Unders. 147 (this volume).

Pickerill, R. K., Fillion, D. \& Harland, T. L. 1984: Middle Ordovician trace fossils in carbonates of the Trenton Group between Montreal and Quebec City, St. Lawrence Lowland, eastern Canada. J. Paleont. 58, 416-439.

Poulsen, V. 1974: Olenellacean trilobites from eastern North Greenland. Bull. geol. Soc. Denmark 23, 79-101.

Quatrefages, M. A. de 1849: Note sur la Scolicia prisca (A. De. Q.), annélide fossile de la Craie. Ann. Sci. Nat., sér 3, Zool. 12, 265-266.

Schaffer, F. X. 1928: Hormosiroidea florentina n. g., n. sp., ein Fucus aus der Kreide der Ungebung von Florenz. Paläont. Zeitschr. 10, 212-215.

Seilacher, A. 1955: Spuren und Lebensweise der Trilobiten; Spuren und Fazies im Unterkambrium. In Schindewolf, O. H. \& Seilacher, A. (edit.) Beiträge zur Kenntnis des Kambriums in der Salt Range (Pakistan). Akad. Wiss. Lit. Mainz, math.-nat. Kl. 10, 11-143.

Seilacher, A. 1956: Der Beginn des Kambriums als biologische Wende. Neues Jahrb. Geol. Palaeont. Abhandl. 103, 155180.

Seilacher, A. 1960: Lebensspuren als Leitfossilien. Geol. Rund. 49, 41-50.

Seilacher, A. 1970: Cruziana stratigraphy of 'non-fossiliferous' Palaeozoic sandstones. In Crimes, T. P. \& Harper, J. C. (edit.) Trace fossils. Geol. J. Spec. Issue 3, 447-476. Liverpool: Seel House Press.

Torrell, P. 1870: Petrifacta Suecana Formationis Cambricae. Lunds Univ. Arsskr. 6, 1-14.

Trewin, N. 1976: Isopodichnus in a trace fossil assemblage from the Old Red Sandstone. Lethaia 9, 29-37.

Webby, B. D. 1983: Lower Ordovician arthropod trace fossils from western New South Wales. Proc. Linn. Soc. N.S.W. 107, 59-74. 